\title{
Liçóes para ser o cronista do rei: um estudo dos Diálogos sobre quem deve ser o cronista do principe, de Pedro de Navarra
}

Apresentação e tradução Maria Emília Granduque José1* ${ }^{1}$ Universidade Estadual Paulista Júlio de Mesquita Filho, Franca/SP - Brasil

\section{RESUMO}

No século XVI, a Espanha foi palco de uma série de escritos que visavam definir não apenas as regras que deveriam conduzir a escrita da história, mas também as qualidades esperadas de um bom cronista. Justificavam os autores dessas obras que a imagem de um reino e, consequentemente, de seu governante, construía-se a partir da história elaborada pelos letrados encarregados de registrar o passado. A partir do estudo dos Dialogos qual debe ser el chronista del principe, composto por Pedro de Navarra e publicado em 1565, a proposta desta apresentação crítica é interrogar como os letrados definiram o ofício do cronista e historiador na sociedade espanhola dessa época. Além dessa questão central, o texto tem como alvo apresentar a tradução comentada dos Dialogos qual debe ser el chronista del principe com o objetivo de guiar a análise sobre as funçôes atribuídas ao cronista do rei, bem como os requisitos necessários para o exercício desse ofício.

Palavras-chave: Espanha; século XVI; Pedro de Navarra; Diálogos; cronista.

\section{Lessons to be the King's Chronicler: a study of the Diálogos sobre quem deve ser o cronista do principe [Discussions about who should be the prince's chronlicer], by Pedro de Navarra}

\footnotetext{
ABSTRACT

In sixteenth-century Spain, scholars published a series of texts aimed at defining both the rules that should guide the writing of history and the desired qualities of a good chronicler.

DOI: http://dx.doi.org/10.1590/2237-101X02104502

Tradução recebida em 31 de março de 2020 e aceita para publicaçáo em 3 de junho de 2020.

* Pós-doutoranda em História pela Universidade Estadual Júlio de Mesquista Filho - UNESP campus Franca com bolsa FAPESP (processo 2017/22523-6). Membro do Projeto Temático, financiado pela FAPESP, "Escritos sobre os Novos Mundos: uma história da construçáo dos valores morais em língua portuguesa" (Processo 2013/14786-6). E-mail: memiliagranduque@gmail.com. ORCID: ORCID: https://orcid.org/00000003-2724-4286.
} 
The authors of these works argued that the image of a kingdom, and, consequently, its ruler, was formed based on the writings of those scholars in charge of recording the past. This study analyses Pedro de Navarra's 1565 text Dialogos qual debe ser el chronista del principe in an effort to understand how scholars defined the positions of chronicler and historian in Spanish society during this period. In addition, this article presents an annotated translation of Dialogos in order to bolster analysis of the king's chronicler's assigned functions and requirements.

Keywords: Spain; $16^{\text {th }}$ century; Pedro de Navarra; Dialogues; chronicler.

\section{Lecciones para ser el cronista del rey: un estudio de los Diálogos sobre quién debe ser el cronista del príncipe, de Pedro de Navarra}

\section{RESUMEN}

En el siglo XVI, España fue el escenario de una serie de escritos que apuntaban a definir no sólo las reglas que deberían llevar a la escritura de la historia, sino también a las cualidades esperadas de un buen cronista. Justificaban los autores de esas obras que la imagen de un reino y, consecuentemente, de su gobernante, se construía a partir de la historia elaborada por los letrados encargados de registrar el pasado. A partir del estudio de los Dialogos qual debe ser el chronista del principe, compuesto por Pedro de Navarra y publicado en 1565, la propuesta de esta presentación crítica es preguntarse cómo los letrados definieron el oficio del cronista e historiador en la sociedad española de esta época. Además de esta cuestión central, este texto tiene como objetivo mostrar la traducción comentada de los Dialogos qual debe ser el chronista del principe con el propósito de guiar el análisis sobre las funciones atribuidas al cronista del rey, así como los requisitos necesarios para el ejercicio de esta profesión.

Palabras clave: España, siglo XVI, Pedro de Navarra, Diálogos, cronista.

\section{Apresentação à tradução}

[...] se os bons príncipes têm a obrigação de ser exemplares em suas vidas e de ter pessoas que refiram seus atos bons e maus, como se fossem juízes superiores com o poder de condená-los ou absolvê-los, não deveriam descuidarse na escolha de tais pessoas, assegurando que sejam verdadeiras, sucintas e abundantes no dizer, assim como 
autênticas, sérias e fiéis ao escrever, pois de sua ordenaçáo e pena dependem a honra e o renome do príncipe famoso ou infame para sempre. Digo para sempre porque, embora os grandes e fortes edifícios acabem com a ação do tempo e as nações pereçam de mão em mão com a velhice, a escrita permanece enquanto o mundo durar [...] (NAVARRA, 1567, Epístola).

Assim escreve o eclesiástico Pedro de Navarra, na epístola dos Diálogos sobre quem deve ser o cronista do principe ${ }^{2}$, publicado em 1565, ao refletir sobre a importância de se escolher bons cronistas para narrar a história oficial do reino. Comparando a autoridade do historiador de arbitrar sobre os atos praticados no passado com a do juiz de sentenciar os feitos empreendidos no presente, o autor anuncia os cuidados que o monarca deveria tomar na escolha de quem exerce esse ofício. Mais precisamente, direcionando sua mensagem ao rei Felipe II, como consta na página inicial da obra, ele busca mostrar que a eleição do cronista tem de ser criteriosa, respeitando, para isso, uma série de condições essenciais ao exercício do cargo, já que a boa memória do soberano depende de quem irá registrá-la para as geraçóes futuras.

Escrevendo em uma Castela do século XVI, época em que o cargo de cronista real já estava consolidado desde a sua criação no reinado de Juan II (1406-1454) ${ }^{3}$, Navarra apresenta as diretrizes fundamentais que deveriam conduzir a escrita da história oficial feita no âmbito da corte. Lançando luz aos compromissos inerentes ao ofício de cronista, como, entre outros, a responsabilidade de narrar os fatos de forma isenta e sem comprometimento com um dos lados, esse autor é um dos primeiros letrados espanhóis a dedicar uma obra específica sobre essa temática. Ao lado de nomes como Gonzalo Fernández de Oviedo, que descreve as obrigaçóes do cronista junto aos diferentes cargos criados para gerir a monarquia no seu Libro de la Cámara Real del príncipe Don Juan, datado de 1548, e de Rodrigo Espinosa y Santayana, que define, um pouco depois, na Arte de retórica de 1578, a arte do historiador, Navarra projeta na sua obra qual o perfil ideal de quem exerceria a tarefa de conservar os eventos do passado.

As orientaçóes presentes no seu Diálogo, encenado em cinco atos pelos personagens Cipriano e Basílio, estão muito próximas das diretrizes formuladas pelos autores do século $\mathrm{XV}$ que também problematizaram a postura adotada pelos cronistas oficiais. Em outras palavras, as críticas lançadas por Navarra ao modo como os cronistas construíam as suas histórias repercutem certos questionamentos feitos anteriormente por letrados que denunciavam em suas obras os deslizes cometidos por quem estava a cargo desse ofício. No prólogo

\footnotetext{
${ }^{2}$ No original, Dialogo qual debe ser el chronista del principe.

${ }^{3} \mathrm{O}$ cargo de cronista oficial e remunerado foi ocupado primeiramente por Juan de Mena.
} 
das Generaciones y semblanzas, obra datada de 1450, Fernán Pérez de Gusmán ${ }^{4}$, por exemplo, condena os cronistas que se mostravam partidários dos seus governantes durante a composição da narrativa. Referindo-se especificamente a Pedro de Corral, escritor da Corónica Serracina, esse autor acusa-o de distorcer os fatos em benefício de uma parte a tal ponto de dar fama a quem não deveria em prejuízo daqueles que realmente mereciam ser reconhecidos. Uma das razóes para essa conduta, segundo ele, estava no fato de que o cronista escrevia a mando do rei e, para não contrariá-lo, fazia da sua história um registro mais para agradar o governante do que para conservar a memória do reino (PÉREZ DE GUSMÁN, 1790, p. 278). Na visão de Pérez de Guzmán (p. 276), a dependência desse oficial em relação ao monarca, firmada, sobretudo, em razão do salário e do título fornecidos pelo cargo, era um impedimento para uma escrita imparcial da história.

Criado com o intuito de promover uma versão autorizada da memória do reino, em meio a tantas outras que circulavam sem passar pelo crivo da coroa, o cronista oficial tinha como meta registrar com verdade as vitórias alcançadas no seu tempo. A sua posição permitia-lhe transitar pelo ambiente da corte, ter acesso aos documentos e aos despachos oficiais e até mesmo acompanhar o monarca durante as viagens e os eventos políticos ora como testemunho presencial dos fatos que iria contar, ora como conselheiro do governante. Esse historiógrafo matinha, como se vê, certo prestígio em relação aos outros funcionários da Casa Real e não arriscaria perdê-lo com uma escrita que desagradasse alguma personalidade da cena nobiliária. Não é sem razão que ele serviu, em muitas circunstâncias, como um braço do aparato administrativo da monarquia em defesa dos interesses particulares de quem reinava, sobretudo em uma época conturbada por guerras internas em que as disputas dinásticas não se davam somente no campo diplomático, mas também se realizavam no campo da história usada pelos governantes para legitimar suas açôes frente às críticas e às depreciaçóes veiculadas pelos seus opositores 5 .

Essa crítica ao partidarismo dos cronistas oficiais, manifestada, inicialmente, nos prólogos das obras do século XV, punha em debate a própria finalidade da história produzida nesse ambiente. Para alguns dos críticos, como Pérez de Guzmán, o cronista que compunha a sua narrativa conduzido por pressóes políticas não atuava de acordo com as atribuiçôes do cargo, que consistiam, desde a sua criação, em espelhar os eventos ocorridos na sua época contando tanto as boas açôes protagonizadas pelos reis como as más condutas que haviam sido praticadas. Referindo-se ao propósito moralizante da história de conservar os feitos empreendidos no presente para que sirvam de modelos às geraçóes futuras, esse autor consi-

\footnotetext{
${ }^{4}$ Beatrice Léroy (2013) apresenta um importante estudo sobre o perfil do cronista descrito nas Generaciones y semblanzas de Fernán Pérez de Guzman.

${ }_{5}^{5}$ De acordo com Pedro Henández Martínez (2013, p. 240), “[...] en el fracturado mapa europeo, los reinados serán los hilos conductores de las crónicas y, en el caso que se analiza, la historia oficial, de naturaleza política - que será la característica hasta bien entrado el siglo XX - enaltecerá la personalidad y los hechos de quienes dirigían los estados y las monarquías occidentales [...]".
} 
derava que um dos graves problemas trazidos por esse tipo de narrativa seria a confirmação de um hábito de que, para serem lembrados, os homens não precisassem mais se esforçar para praticar atos virtuosos em proveito de seus reinos se havia cronistas encarregados de construir uma imagem favorável de suas açôes. Mais precisamente, esse autor alerta, ainda no século XV, que os homens não buscariam ser eternizados pelos seus feitos, mas, sim, pelo resultado de uma escrita elaborada por cronistas capazes de manipular a narrativa a favor de seus interesses.

A denúncia de Pérez de Guzmán acerca do modo como os cronistas direcionavam o relato é um dos assuntos retomados por Pedro de Navarra na epístola que abre os seus Diálogos sobre o cronista do rei. Dirigindo-se ao monarca Felipe II, esse autor lembra a finalidade das crônicas de noticiar as boas obras para que sejam aproveitadas, segundo as suas próprias palavras, "como um perfeito exemplo para todas as naçóes presentes e vindouras nos seus Reinos e nos estranhos" (NAVARRA, 1567, Epístola) ${ }^{6}$. Navarra destaca a necessidade desse governante saber cercar-se de bons cronistas capazes de eternizar seus atos que poderiam inspirar os homens em outras épocas. Já em um dos seus Diálogos, ressalta a importância dessa escolha ao lembrar a influência que os cronistas dispunham nessa função. Diz ele:

Os cronistas são quem fazem presente todo o passado e o que nos fazem perpétuos em todos os séculos futuros. Porque as crônicas sempre vivem e jamais morrem, passando de nação em nação publicando nossos méritos ou deméritos [...]. As crônicas excedem em perpetuidade a todas as pirâmides, colunas, troféus, mármores e todos os outros gêneros de edifícios antigos. São elas que nos dão ser e renome bom ou mau durante todo o mundo. Por essa razão, o cronista deve ser escolhido com grande diligência e prudência, cuidando para que não seja vil, ignorante, interessado, apaixonado, obrigado, vicioso, adulador, audaz, exagerado e mentiroso [...] (NAVARRA, 1567, Diálogo II). ${ }^{7}$

Nesse mesmo Diálogo, Navarra sugere ainda que o monarca não apenas deveria cuidar da escolha de seu cronista, mas também averiguar a conduta adotada por ele durante o exercício desse ofício. Essas recomendaçóes prescritas na sua obra indicam o compromisso do governante de corrigir as eventuais superficialidades e lisonjas que poderiam conter nos escritos produzidos na corte. A complacência de sua parte com esse tipo de crônica seria

\footnotetext{
${ }^{6}$ Traduçáo minha. No original: "como perfecto ejemplo a todas las naciones presentes y por venir en sus Reynos y en los estraños".

${ }^{7}$ Tradução minha. No original: "Estos son los que nos hacen presente todo lo pasado, y los que nos hacen perpetuos en todos los siglos futuros. Porque siempre viven y jamás mueren las crónicas, sino que van de nación en nación publicando nuestros meritos, o demeritos [...]. Estas exceden en perpetuidad a todas las pirámides, columnas, trofeos, marmores y todos los otros géneros de edificios antigos. Estas son los que nos dan ser y renombre bueno o malo para durante el mundo. Y por tanto debe ser electo el cronista con gran diligencia, y prudencia, no vil, no ignorante, no interesado, no apasionado, no obligado, no vicioso, no adulador, no audaz, no verboso ni mentiroso [...]".
} 
considerada uma infâmia, no parecer de Navarra, no momento em que se percebesse o consentimento para a composiçáo de histórias alheias à verdade. $\mathrm{O}$ resultado não poderia ser mais desastroso para a imagem do monarca: alguém que não se poderia fiar. Para não incorrer nesse erro, o soberano teria de ser exemplar em sua trajetória de vida a tal ponto que o cronista oficial não precisasse manejar os fatos com o intuito de favorecer o seu legado.

Mas, embora Navarra tenha destacado o papel dos governantes para assegurar a narrativa correta da história, os questionamentos mais exaustivos dos letrados da sua época referiam-se à conduta assumida por esses cronistas. Lorenzo Galíndez de Carvajal, figura marcante na corte de Carlos V, ao dissertar sobre a importância dos governantes investirem em histórias que reflitam as suas açôes e os seus interesses, não deixou de alertar o mau caminho pelo qual muitos cronistas seguiam ao adular e agradar quem patrocinava a sua escrita (KAGAN, 2010, p. 103). Segundo ele, os cronistas vinculados à corte e, portanto, dependentes do cargo, estavam mais suscetíveis a distorcerem os fatos na composição da história oficial. Na condição de censor das crônicas, posto que lhe fora dado para controlar as obras produzidas nesse ambiente, Carvajal lembra que ao agirem assim esses cronistas desvirtuavam o propósito principal de seu ofício: registrar com clareza e verdade os acontecimentos do seu tempo. Propósito recordado por Gonzalo de Oviedo, letrado que havia servido na corte de Juan II no período em que se instituiu esse cargo, ao descrever os deveres e os limites dados a esse oficial. No verbete que integra o seu Libro de la Cámara Real del príncipe Don Juan ${ }^{8}$, declara que o ofício de cronista comparava-se ao de um evangelista dado o seu compromisso quase religioso de ser fiel no exercício do seu labor historiográfico. Retomando a definição de Juan de Flores, para quem os cronistas eram evangelistas temporais (BAUTISTA PÉREZ, 2015, p. 103), Oviedo destaca o dever desse historiógrafo de produzir um relato comprometido com a verdade das matérias que buscava registrar (FERNÁNDEZ DE OVIEDO, 2006, p. 163).

Consenso entre os letrados, esse compromisso com a verdade aparece nesses textos como a condição principal para aqueles encarregados oficialmente de registrar o passado. Pedro de Navarra, por exemplo, considerava que era "tão essencial o cronista ser verdadeiro [...] que, ao não sê-lo, afronta a si mesmo, engana e (às vezes) infama o príncipe, mingua a República e toda a sua nação" (NAVARRA, 1567, Diálogo II). ' Tendo como meta prescrever de que modo o cronista do rei poderia agir para ser verdadeiro em sua narrativa, Navarra pondera a necessidade de ele ser neutro, autêntico e "tão livre e senhor de si que pura e sinceramente escreva somente a verdade, sem temor, amor, interesse, paixão ou obrigação" (NAVARRA,

\footnotetext{
${ }^{8}$ No estudo preliminar da edição do Libro de la Cámara Real del príncipe Don Juan, Santiago Fabregat escreve que essa obra é fruto de um pedido do monarca Felipe II para que Gonzalo de Oviedo relate com detalhes os "usos y ofícios seguidos en la casa y corte del principe Don Juan" (FERNÁNDEZ DE OVIEDO, 2006, p. 43).

${ }^{9}$ Tradução minha. No original: "tan esencial ser vero el cronista [...] que al no serlo afrenta a si mismo, engaña e (a veces) infama al príncipe, y mengua a su rep. y toda su nación”.
} 
1567, Diálogo II $)^{10}$ por ninguém. Mais precisamente, o cronista teria de ser livre para contar os fatos tal como sucederam sem o receio de que a sua história causasse desagravos e constrangimentos a algum personagem. Refletindo sobre a importância de o cronista possuir essa liberdade, Lorenzo de Carvajal, a exemplo do que já havia aconselhado Juan Pérez de Guzmán no século $X V^{11}$, recomenda a publicação da crônica somente após a morte das figuras ali representadas para evitar que esse narrador não se indispusesse com nenhuma das partes. A publicaçẫo a posteriori também dava ao cronista mais chances de que sua obra circulasse sem intervençôes do poder real, pois, embora ele mantivesse o controle da narrativa, o monarca poderia agir sobre os conteúdos apresentados sempre que desejasse ${ }^{12}$.

O testemunho presencial do cronista nos eventos que seriam contados no seu relato era uma condiçáo igualmente valorizada. Os letrados consideravam que o cronista dispunha de muito mais autoridade e fé para contar a sua história quando havia sido ele a sua própria fonte de conhecimento. Pedro de Navarra, aliás, menciona o exemplo dos "quatro santos cronistas de Jesus Cristo que mais particularmente nos deixaram escritas tanto as palavras que disse como os milagres que operou" (NAVARRA, 1567, Diálogo III) ${ }^{13}$ para afirmar a sua tese de que o cronista tem de estar sempre próximo do monarca e, se possível, participar da sua agenda política de forma a vivenciar os episódios que pretende registrar. Tal proximidade também possibilitava a assimilação das palavras pronunciadas pelos governantes que, na opiniáo desse autor, mostravam-se tão importantes quanto os seus atos e, muitas vezes, até mais expressivas para o cronista reproduzir com fidelidade os fatos da vida desse personagem. Desdobrando melhor esse argumento, Navarra chega a recomendar, inclusive, que o cronista atue como secretário ou conselheiro privado do rei de modo a se inteirar, segundo ele, das "causas essenciais de todos os atos, coisas e casos que podem ser escritos" (NAVARRA, 1567, Diálogo III) ${ }^{14}$. De forma semelhante, Lorenzo de Carvajal, embora não amplie a funçáo do cronista como Navarra, ressalta no seu texto a importância desse oficial acompanhar pessoalmente os episódios que se dispunha a contar e, quando não fosse possível, procurasse se informar com os testemunhos que lá estivessem presentes como forma de assegurar a fidelidade do seu relato (KAGAN, 2010, p. 104).

\footnotetext{
10 Traduçáo minha. No original: "tan libre y señor de si, que pura y sinceramente ose escribir verdad, sin temor, amor, interese, pasión ni obligación”.

${ }^{11}$ No prólogo da obra Generaciones y semblanzas, Pérez de Guzmán (1790, p. 277) escreve que para a história ser bem feita era necessário que "[...] no sea publicada viviendo el Rey ó Príncipe en cuyo tiempo y señorío se ordena, porque el Historiador sea libre para escribir la verdad sin temor."

${ }^{12}$ Francisco Bautista Pérez (2015, p. 108) cita o exemplo das intervençóes feitas pela rainha Isabel nos textos de seus cronistas oficiais, Alfonso de Palencia e Fernando de Pulgar.

${ }^{13}$ Tradução minha. No original: "santos cuatro cronistas de Jesus Cristo, que tanto o más particularmente nos dejaron escritas las palabras que dijo como los milagros que obró".

${ }^{14}$ Tradução minha. No original: "causas esenciales, de todos los actos, cosas y casos que son de escrebir".
} 
Além do comprometimento com a verdade e com a neutralidade em sua composição, o bom cronista deveria ser sábio para entender as diferentes matérias tratadas na sua obra e douto para saber declará-las com eloquência e erudição ao público leitor. Em seus Diálogos, Navarra orienta que o domínio da escrita seria fundamental para contar corretamente as açóes praticadas pelo governante e instruir o leitor a partir dos exemplos ali apresentados (NAVARRA, 1567, Diálogo III). A escrita clara e elegante ${ }^{15}$ também era a condição necessária para que o cronista oficial pudesse narrar à altura os grandes eventos protagonizados pelos monarcas mencionados na sua história. Não é sem razão que para esses autores nem todos poderiam se ocupar da tarefa de narrar o passado, já que todas essas condiçóes postas para o exercício desse ofício só poderiam ser cumpridas por uns poucos letrados.

\section{Pedro de Navarra}

Personagem presente na cena cortesã espanhola, Pedro de Navarra ou Pedro de Albret, descendente bastardo do rei de Navarra, Juan II de Albret, viveu entre 1504-1567 em um ambiente político marcado pelas disputas travadas entre a dinastia de Navarra e a casa dos Habsburgos da qual descendia o monarca espanhol ${ }^{16}$. De formaçáo religiosa obtida no monastério beneditino de Santa María la Real de Irache e nos monastérios de San Pedro de Cardeña y Sahagún, condição que o levou à nomeação tardia como bispo de Cominges, em 1561, esse autor também trilhou uma reconhecida carreira diplomática representando os interesses da sua casa real em diferentes centros de poder. Uma atuação que lhe garantiu acesso direto às comitivas reais, como a expedição à Argel, em 1541, na qual participou ao lado do monarca Carlos V, e aos espaços régios, como as estâncias em Roma, onde passou um primeiro período na condição de embaixador de seu irmão, Enrique II de Navarra, e na corte de Felipe II, local em que permaneceu até 1559. A sua vivência nestes espaços permitiu-lhe conhecer de perto os bastidores do jogo político da época que serviráo como pano de fundo para muitas das suas obras. A escrita dos Diálogos de la diferencia del hablar al escribir, por exemplo, retrata o primeiro momento passado em Roma quando há uma série de proibiçóes papais, como, entre outras, a regulaçâo de certos modos de falar e de escrever. Já a composição dos célebres Diálogos de la eternidad del ánima e dos Diálogos de las herejías de Francia expressa as suas impressóes obtidas na passagem pela Aquitânia em uma época conturbada pelas guerras de religiáo.

\footnotetext{
${ }^{15}$ Pode-se entender que Pedro de Navarra, embora náo escreva os seus Diálogos em latim, repercute a ideia humanista recorrente entre os letrados dessa época de que a elegância do texto constitui uma das condiçóes para a atividade intelectual (CABELLO PORRAS, 2008, p. 107).

${ }^{16}$ As etapas da vida e a produçáo da obra de Pedro de Navarra podem ser consultadas em Gońi Gaztambide (1990, p. 559-596).
} 
A atuação de Pedro de Navarra nesses espaços de poder também deu-lhe acesso ao ambiente letrado frequentado pelos nomes mais ilustres da cena espanhola da época, como a academia de Valladolid, visitada entre 1540 e 1546 (GOÑI GAZTAMBIDE, 1990, p. 560), para discutir temas relacionados à filosofia, história e literatura, segundo o próprio autor registra em uma de suas obras:

Entre as academias frequentadas por varóes ilustres no tempo em que eu estava na corte daquele invictíssimo César, vencedor de si mesmo, era a casa (e não das últimas) do notável e valoroso Hernán Cortés, engrandecedor da honra e do império de Espanha, cuja conversação seguiam muitas pessoas assinaladas de diversas profissōes pela sua grande experiência e feitos admiráveis [...] (NAVARRA, 1565, p. 43). ${ }^{17}$

Essa foi uma experiência que certamente pesou na hora de compor a maior parte das suas obras, como os Diálogos de la preparación de la muerte, escritos justamente no momento em que os letrados ali reunidos discutiam o ordenamento que todo verdadeiro cristáo deveria seguir para se preparar para a morte. Essa experiência de Pedro de Navarra e a sua vivência no ambiente cortesão devem ter igualmente contribuído para a escrita dos Diálogos cual debe ser el chronista del Principe, alvo deste estudo, se considerarmos a afirmativa do próprio autor ao reconhecer todas as matérias tratadas pelos varôes dessa academia como sendo tão notáveis "[...] que nos duzentos diálogos que eu escrevi há muitas poucas coisas que não tenham sido tratadas nesta excelente academia" (NAVARRA, 1565, p. 43) ${ }^{18}$. Dirigida para um público especializado, a obra de Pedro de Navarra é o reflexo da atuação do autor na esfera política e religiosa e, justamente por isso, ajuda-nos a compreender tanto os bastidores da Espanha quinhentista e dos reinos vizinhos elencados nos seus diálogos, caso da França, como os valores apreciados pelos homens dessa época que aparecem divulgados por meio da fala de seus personagens.

\footnotetext{
${ }^{17}$ Tradução minha. No original: "Entre las academias que había de varones ilustres en el tiempo que yo seguía la corte de aquel invictíssimo César, vencedor de sí mismo, era una (y no de las postreras) la casa del notable y valeroso Hernán Cortés, engrandecedor de la honra e império de Espańa, cuya conversación seguían muchas personas señaladas de diversas profisiones por su grande experiência y hechos admirables [...]." Tradução minha. De acordo com Pedro de Navarra (1565, p. 43), a dita academia era frequentada pelo "[...] liberal Cardenal Poggio, el experto Dominico Pastorelo Arçobispo de Callar, el docto fray Domingo del Pico, el prudente don Joan Deztuñiga Comendador mayor de Castilla, el grave y cuerdo Joan de vega, el inclyto don Antonio de Peralta Marques de Falces, don Bernardino su hermano y otros que por no ser largo dexo de nombrar".

${ }^{18}$ Traduçáo minha. No original: "[...] que en doscientos dialogos que yo he escrito, hay muy pocas cosas que en esta excelente academia no se hayan tocado".
} 


\section{Dados e descrição da edição consultada}

Os Diálogos cual debe ser el chronista del Principe, alvos deste estudo, estão presentes em uma coleção de diálogos escritos por Pedro de Navarra e publicados pelo impressor Jacobo Colomerio, em Toulouse, na data de 1567. A coleção contém quatro diálogos - Diálogos de la differencia del hablar al escribir; Diálogos cual debe ser el chronista del Principe; Diálogos de la diferencia que hay de la vida rustica a la noble; Diálogos de la preparación a la muerteque somam um total de 128 fólios, juntando os prólogos, epístolas ou cartas dedicatórias que antecedem cada um dos textos.

A obra contém 20 fólios, uma epístola e cinco diálogos travados entre dois personagens, Cipriano e Basílio, que também aparecem nos Diálogos de la preparación de la muerte. Seguindo o padrão dos diálogos elaborados na Espanha desse período, a obra está escrita em espanhol ${ }^{19}$ possivelmente para ajustar-se à comunicação em língua vernácula que pouco a pouco vinha sendo adotada nas produçôes escritas do reino ${ }^{20}$. Quanto ao conteúdo abordado, o texto pode ser definido como um jogo de perguntas e respostas ordenadamente criadas por Pedro de Navarra com a finalidade de explicar mais claramente ao leitor o papel do cronista real e os atributos necessários para o exercício desse ofício.

\section{Descrição da obra}

A primeira página do diálogo traz uma epístola do autor dirigida ao católico rey de España Don Phelipe de Austria, segundo deste nombre em um pouco mais de um fólio. Nessa parte, Pedro de Navarra, seguindo o esquema utilizado pela maior parte dos autores da sua época, reserva as palavras iniciais para expor ao leitor as razóes que o levaram a discutir a matéria debatida em sua obra ${ }^{21}$. Partindo de um exemplo religioso, esse autor explica que, assim como Jesus Cristo teve as suas boas açôes registradas e conhecidas pelas geraçôes futuras, os príncipes cristãos também deveriam agir corretamente para serem bem lembrados e se cercar de beneméritos cronistas que narrassem os seus atos, as suas palavras e as suas vidas. Os cinco diálogos que aparecem em seguida trazem o debate dessa questão central entre dois amigos, Cipriano e Basílio.

\footnotetext{
${ }^{19}$ De acordo com Jacqueline Ferreras (2002, p. 5), “[...] l'usage de la langue vernaculaire représentait un aspect caractéristique du Dialogue espagnol du XVIe siècle".

${ }^{20}$ Segundo Gregorio Porras (2008, p. 108), a língua espanhola vai se tornando internacional ao ser falada entre damas e cavalheiros do império. A causa desse fator, escreve ele, "[...] está la consciência de ser un pueblo dominante y lo que L. Gil Fernández denomina 'el slogan de Nebrija de 'la lengua compañera del imperio', que contribuyeron al desuso del latín como lengua de relación en una monarquia multinacional y plurilíngue. Además de estas razones políticas, el desuso del latín también contaba entre sus causas con factores que afectaban de lleno a la difusión del conocimiento y de la ciencia”.

${ }^{21}$ Para Asunción Rallo Grus (1996, p. 13), os diálogos renascentistas trazem essa primeira parte ou preparatio com o objetivo de apresentar ao leitor um resumo do que será desenvolvido na obra.
} 


\title{
Diálogos sobre quem deve ser o cronista do príncipe. Matéria ainda pouco tratada. Dirigidos ao Rei de Espanha dom Felipe de Áustria, segundo deste nome
}

\author{
Ditados pelo ilustríssimo Reverendíssimo Senhor dom Pedro de Navarra (por graça de \\ Deus) Bispo de Comenge, do Conselho do Cristianíssimo Rei da França. \\ Epístola do autor para quem direciona a obra.
}

S. C. R. M.

As crônicas têm muita autoridade e utilidade para a honra e o renome dos príncipes. Assim mostra o príncipe da paz e pai do século futuro por meio de seus quatro evangelistas ${ }^{22}$ que, se não lhes tivessem fé e não narrassem a mera e pura verdade dos atos de Cristo, haveríamos ignorado a uniáo de sua divindade com a humanidade e todos os outros mistérios, como a perfeição da vida, o exemplo e a doutrina realizados pelo nosso redentor Jesus Cristo. Nosso senhor ordenou a esses quatro cronistas ${ }^{23} \mathrm{e}$ orientou que tratassem principalmente dos mistérios da Divindade e dos outros dois da humanidade para que, mediante a sua escrita, todas as naçóes conhecessem sua uniáo de Divino e humano com o propósito náo apenas de alcançar a redenção daqueles que o cressem e buscassem o batismo, mas também para ter fama de redentor do gênero humano e título de Deus e homem. Digo isso para que, a exemplo de Jesus Cristo, os príncipes cristãos estejam obrigados a resplandecer de luz de vida perfeita e de atos tão excelentes que glorifiquem neles Deus que está nos céus, como também a ter beneméritos cronistas que narrem seus atos e ainda suas palavras e vidas para dar mais perfeita notícia de suas boas obras, colocando-as em perpétua memória para louvar o criador a partir delas e para que os próximos aproveitem como manda o Sagrado Evangelho: que nenhum acenda a vela e a coloque debaixo da medida (porque seria sem fruto, tal como o talento escondido), a náo ser sobre o candelabro de sua limpa e pura consciência, onde ilumine de perfeito exemplo para todas as naçóes presentes e do porvir em seus Reinos e nos estranhos. De maneira que se os bons príncipes têm a obrigação de ser exemplares em suas vidas e de ter pessoas que refiram seus atos bons e maus, como se fossem juízes superiores com o poder de condená-los ou absolvê-los, não deveriam descuidar-se na escolha

\footnotetext{
${ }^{22}$ Pedro de Navarra faz referência aos quatro evangelhos conhecidos pelos nomes de seus autores - Mateus, Marcos, Lucas e João - contidos no Novo Testamento da Bíblia que narram a vida e as liçóes de Jesus.

${ }^{23}$ No texto original, o vocábulo cronista vem grafado como chronista. Trata-se de uma grafia muito comum nos textos dessa época, assim como coronista e somente cronista. No seu tratado Genio de la Historia, de 1650, Jerónimo de San Jose (1768, p. 40-41), ao discorrer sobre as muitas denominação que se dava para a história, escreve que "Chama-se também Crônica [...], embora os precisos eruditos sempre retêm a propriedade Grega, dizendo Crônica e Cronista, e ainda a ortografia daquela língua escrevendo Chronica, coisa já desnecessária e que segundo a regra de Horácio se deve ceder ao uso que pronuncia e escreve Crônica e Cronista. É, pois, Coronica a História difusa de alguma República eclesiástica, religiosa ou secular, ajustada aos anos mesmo que não tão restrita e precisamente como os Anais ou Diários".
} 
de tais pessoas, assegurando que sejam verdadeiras, sucintas e abundantes no dizer, assim como autênticas, graves e fiéis ao escrever, pois de sua ordenação e pena dependem a honra e o renome do príncipe famoso ou infame para sempre. Digo para sempre porque, embora os grandes e fortes edifícios acabem com a ação do tempo e as naçôes perecem de mão em mão com a velhice, a escrita permanece enquanto o mundo durar e sempre noticiará todas as naçôes que haverão enquanto haja homens e farão presente o Rei de quem se escreve, em pessoa, vida e costumes como se pessoalmente o vissem e o tratassem. Ainda que eu saiba bem que V. M. fez uma escolha decente nesse caso, escrevo este breve discurso (qual deve ser tal historiógrafo) para exercitar um pouco a sentença clara e excelente de vossa Majestade ao qual (embora emérito) me refiro, recompense meu empenho e pequeno serviço.

\section{DIÁLOGO I}

\section{Cipriano Basílio}

Cipriano: Que a paz esteja convosco, amigo Basílio. Basílio: Convosco também. Cipriano: Em que pensas tão aflito? Basílio: Nos trabalhos que a guerra ${ }^{24}$ tem causado em Roma e na pouca esperança que se tem da paz. Cipriano: O que precede a isso, porque, desde que sou homem, escuto sempre dizer que há guerra na Itália? Basílio: A causa é que Roma é invejada e desejada pelos estranhos e sofre com as parcialidades e ambiçôes de seus naturais. Cipriano: O que provocou na Itália a ambição e o governo das naçôes que a inquietam? Basílio: Sua pouca união e muita discórdia ao haver quem se deixa perder seu Estado e amigos para vingar-se de seus inimigos. E como não bastasse fazer isso, sem ajuda de outro, deixa-se fazer de senhor a escravo para fazer também escravo a seu inimigo que era senhor. Cipriano: Logo, esta divisão tem sido a causa da sua sujeição? Basílio: Isso mesmo, pois se todas as suas Repúblicas viessem a estar em constante união não dariam brechas para uns sujeitá-la nem dariam trabalho para outros defendê-la. Cipriano: Eu havia entendido que a guerra procedia da inquieta natureza de uns e da demasiada liberdade de outros. Basílio: Náo estás longe da verdade. Nas coisas de Estado e liberdade às vezes se desconhece o filho ao pai e o menor ao maior. Embora este seja um vício comum de todas as naçôes, parece que isso é mais particular desta que tratamos. Cipriano: Qual a razão? Basílio: Da liberdade que dissestes e de não querer admitir um príncipe próprio que os ampare, mas a estranhos que os dominem. Cipriano: De sorte que disso causa inquietação na sua gente e guerras que destoem suas Repúblicas. Basílio: Isso mesmo. Cipriano: Eu vejo bem que é esta a causa essencial de sua destruição e que por trás da culpa vem a pena. Mas ouvi dizer de outros que suas divisóes e guerras continuadas procediam de seus potentados serem parciais e aciden-

\footnotetext{
${ }^{24}$ Basílio faz referência às convulsôes políticas que marcaram Roma durante o papado de Paulo IV e ao desequilíbrio nesse território por conta das interferências exteriores.
} 
tais, e, às vezes, violentos. E que o violento dura pouco. Basílio: É verdade que a aflita Itália tem Estados tão divididos que toda ela consiste em Repúblicas parciais ou em senhorios parciais e acidentais, de modo que a divisão das Repúblicas e a parcialidade dos senhores procedem à divisão que acima mencionei e que dessa divisão vem o ódio e desse a vingança e, para realizar a vingança, deixam de lado a vida, o Estado e a República. Essas duas coisas forçosamente causam a perda de vidas e de Estados e sujeitam a sua população e República às naçôes estranhas. Não há lá nenhum excelente varão que se compadeça desses problemas que padece a Itália? Basílio: Até agora cada um tem seguido sua paixão e interesse particulares sem lembrar o bem comum. Agora parece que Deus, com sua imensa bondade, proveio um bom monarca tão bom e valoroso (que, por ser Cardeal, tem prometido) que em breve libertará a madre Itália. ${ }^{25}$ Estou certo de que se as forças chegarem aos seus pensamentos, a Itália será livre e ainda senhora (como em outros tempos) daqueles que agora a tem por serva ou em parte mais inquieta de guerras civis que engendraram outras maiores. Cipriano: Que fim se espera em caso tão grande? Basílio: Os fins e sucessos das guerras são tão duvidosos e os juízos de Deus táo profundos que eu seria mais do que ousado se quisesse responder corretamente à tua pergunta. Bastaria dizer-te que os pensamentos deste santo monarca - que temos por tão santos e excelentes -, se não mudar quando não houver inteiro efeito, ficará com renome perpétuo no mundo somente por haver empreendido essas açôes principais. ${ }^{26}$ Cipriano: Sem dúvida, vejo que sentes tão bem neste caso, pois, para conseguir o que de ti pretendo, é um bom sinal. Para dizer-te a verdade, eu vim visitá-lo com o objetivo de alcançar de ti uma graça, a qual suplico que não me queiras negar pelo amor que tenho e que me tens e pela honra que disso possa seguir. Como (tu vês e confessas), temos um monarca tão ilustre de sangue e de vida, tão distinto e acentuado nas línguas, tão alto e magnânimo em seus pensamentos e fins, táo constante e defensor da Igreja e (como tu dissestes) táo resoluto na liberdade de sua madre Itália que, desde o princípio de seu império, começou a dispor as matérias para efetuar estes táo altos e louváveis fins. Tu, como filho e membro desta República Cristâ, assuma este serviço de escrever a Crônica deste beatíssimo príncipe, assim como fizestes do Papa Paulo III e do Imperador Carlos V. Basílio: A lei da verdadeira amizade só se estende a pedir coisas justas ao amigo. ${ }^{27}$ Cipriano: Chamas injusto pedir-te coisas que outras vezes já fez? Logo, tu és injusto. Basílio: Não procede o que inferes, ainda que não te quero negar que se eu considerar como agora as qualidades que se requerem para ser um bom cronista, pode ser que não tenhas me coibido o que tu dissestes. Cipriano: Quais são as partes que se requerem para que um seja bom cronista? Basílio: No meu parecer são seis

\footnotetext{
${ }^{25}$ Basílio faz referência à nomeaçáo do Papa Paulo IV, em 1555, para governar o pontificado de Roma.

${ }^{26}$ A expectativa de Basílio era de que o reinado do Papa Paulo IV solucionasse os conflitos políticos travados entre franceses e espanhóis pelo domínio da Itália e controlasse o avanço do protestantismo nesse mesmo território.

${ }^{27}$ Cipriano pede a Basílio que ele componha uma crônica dedicada ao Papa Paulo IV assim como havia escrito sobre o Papa Clemente II e o monarca Carlos V.
} 
coisas que se deve ter e sem as quais se fará uma afronta ao príncipe de quem se escreve e também a si mesmo. Porque, meritoriamente, o julgará por ousado e ainda temerário. São essas: Ciência, Presença, Verdade, Autoridade, Liberdade e Neutralidade.

Fim do Primeiro Diálogo

\section{DIÁLOGO II}

\section{Cipriano Basilio}

Cipriano: Que entendes por neutro? Basílio: Entendo que seja sem paixão, inclinação e obrigação. Sem paixão para que não seja inimigo do príncipe de quem se escreve. Sem inclinação para que tampouco seja demasiado seu amigo. Sem obrigação para que não seja natural. Exemplo de nosso monarca, ao qual o espanhol é pouco amigo, o francês é inclinado e o italiano é obrigado. ${ }^{28}$ Cipriano: Logo, não admites o espanhol porque será contrário, nem o francês porque será amigo e tampouco o italiano por ser natural e obrigado. Basílio: Não estou certo se isso conserva o rigor correto e o discernimento. Cipriano: Logo, tu fazes por mim, pois (além das outras qualidades que em ti concorrem) por ser neutro, cabe bem a ti este ofício. Basílio: Se tens paciência de ouvir as outras partes que se requerem, tu perceberás que não me cabe. Cipriano: Prossiga, mas antes declare-me o que entendes por liberdade? Basílio: Chamo livre aquele que não é mercenário nem interessado, porque, se for, dirá por interesse por bens ou por temor ou persuasão que não deve. Como vês, aquele que escreve pelo que lhe dão (como fez Jovio) contam pouca verdade. Aquele que sendo servo escreve sobre o senhor pareceria em algum momento ingrato se com toda verdade e rigor publicasse os males e os vícios de seu patrão. Afinal, se é premiado de estado ou interesse, como quer que diga mal de quem lhe faz bem? Se trata de seu príncipe ou senhor temporal, queres que coloque no varal sua roupa e ainda a vida pelo que escreve sua pena? Se é finalmente neutro e correto, não se deixa perder essa liberdade porque não póe em disputa e perigo sua honra e tranquilidade. Cipriano: Logo, o bom cronista não há de ser criado do príncipe, nem premiado ou interessado, nem obrigado, nem mercenário, nem pusilânime, mas, sim, livre de temor futuro e presente, de interesse de servidão por esperança de mercedes ${ }^{29}$, de promessa e de todo respeito humano e tão livre que nem por amor, temor, nem dádiva jamais escreva coisas fora de seu merecimento? Basílio: Assim entendo. Cipriano: Diga-me,

\footnotetext{
${ }^{28}$ Nessa passagem, Cipriano destaca a animosidade entre o Papa Paulo IV e os imperadores espanhóis Carlos $\mathrm{V}$ e Felipe II, a amizade com os franceses na disputa com os espanhóis.

${ }^{29}$ Merced: "En su riguroso significado, vale el prémio o galardón que se da por el trabajo, especialmente al jornalero. Sale del Latino Merces, edis. Significa tambien dádiva o gracia que los Reyes hacen a sus vasallos, de empleos, dignidades, rentas, \&c. Latín. Gratia. Beneficium”. Diccionario de Autoridades, Tomo IV, 1734. Disponível em: http://web.frl.es/DA.html. Acesso em: 9 nov. 2019.
} 
agora, que chamas por autoridade no cronista? Basílio: Ser claro de sangue, claro em vida e de bom nome e fama. Cipriano: Sem dúvida que ser claro de sangue é uma das principais partes do autêntico cronista: primeiro porque a sua condição priva-o de narrar um caso de diferente maneira como passou, sendo boa a opiniáo que se tem de ser ilustre e ter grande autoridade sobre o que escreve, mais ainda do que os outros vãos, embora todos escrevam igualmente. Segundo, porque quem há de ser autor e juiz das coisas e dos atos dos príncipes e dos grandes precisa ter nascido de pais ilustres, crescido entre eles, criado e amparado sempre em torno de casos e de coisas grandes para que possa escrever, afirmar e julgar os atos dos príncipes com verdade, como pessoa que nasceu e cresceu nesse meio. Basílio: Aí verás que um homem plebeu, por mais douto ou curioso que seja, mostra-se quase impossível medir com a sua pluma os ganhos ou a culpa que merece o príncipe de quem escreve, já que lhe falta a língua interior e termos que contêm a nobreza. Será vil em julgar os atos dos nobres, assim como o cego que julga as cores, pois quando tiver de cumprir seu dever, segundo o que parece ser justo, faltará sempre em algumas coisas próprias da nobreza. De maneira que, embora ao seu parecer julgue justo, sua sentença será sempre injusta aos olhos dos demais. Em geral, esse erro encontrarás entre muitos príncipes que escolhem juízes baixos para julgar pessoas e atos grandes e que escolhem como confessores pessoas nascidas entre o arado e a agulha, sem ciência e experiência. Cipriano: Pouca prudência tem o príncipe que elege por confessor e juiz de sua consciência aquele que ignora por natureza e por muita experiência os atos e as coisas grandes que tratam os príncipes, como seus reinos e consciências, pois, se caso o tal juiz seja douto, ao ignorar as partes e as qualidades que há nos atos régios e nos grandes, pode agravar ou isentar o príncipe em sua confissão. $\mathrm{O}$ mesmo erro é deixar as causas, a vida e a honra dos nobres em mãos daqueles que não o são, a não ser que todos sejam as de um juiz (caso se encontre bom instrumento), porque como o nobre tem a inteligência tal como outro, se exceder na nobreza por maravilha faltará ao que deve como nobre. Basílio: Sinto alívio de que percebestes a geral ignorância que hoje em dia se usa. O mesmo erro é (a meu ver) permitir que um homem baixo escreva coisas e atos de príncipes importantes, pois (como já disse) faltam-lhe a língua natural e os termos próprios da nobreza em este ofício por ter nascido vil e plebeu. Mesmo se ele quisesse se esforçar seria como aquele que finge naturalidade com a arte ou como quem quer fazer da língua alheia coisa natural, pois, por mais que se aproxime da perfeição, jamais encobre seus acentos e faltas completamente ao ponto de não serem reconhecidos. Cipriano: Eu partilho da tua opinião em todos estes três erros, pois os príncipes prudentes jamais devem eleger para juízes de ilustres feitos e crônicas de seus atos, e tampouco para juízes de suas consciências pessoas que não sejam nobres de nascimento nem expertos para contar casos e atos grandes, mas que sejam corretos e virtuosos em suas vidas, magnânimos e únicos em nome e em obra. De sorte que somente temam a Deus e procurem conservar bom nome, porque estes têm inteira autoridade entre os vivos e ainda terão depois de mortos em razão da verdade e retidão com que escrevem, ao 
mesmo tempo que os príncipes permanecerão na memória perpétua ao serem historiados e governados por pessoas de tanta autoridade e virtude. Basílio: Concorda, então, que o bom Cronista deve ser pessoa de autoridade, sangue, livre e neutro se o príncipe quer deixar para a posteridade a sua crônica? Cipriano: Não pensas ser esta opinião se é obra de Jesus Cristo? Não foi Ele quem expressamente revelou na cena a São João os segredos da eterna sabedoria, diante dele, como sendo a pessoa mais nobre e digna dos apóstolos? ${ }^{30}$ Dessa forma, ele mostrou entre todos os cronistas de Cristo mais alteza e excelência porque tratou as coisas da divindade de seu mestre, onde começa: "No princípio era o verbo etc." ${ }^{31}$ Mas São Lucas (como mais terrestre) começa por humanidade. Livro da geração de Jesus Cristo etc., de modo que na matéria sobre a qual escrevem dá a entender (de alguma forma) a natureza onde cada um precede. Verás, assim, que São João é comparado com a águia, que é o príncipe entre as aves. ${ }^{32}$ São Lucas a um novilho, que é servo entre os animais. Basílio: Logo, tu ficas conformado com minha opinião? Cipriano: Sim, porque (me parece) deve ser ilustre ou ao menos nobre. Porque se for vil será como o novo médico que cura: primeiro mata mil sãos antes de curar um enfermo. Basílio: Tu relacionastes bem ao natural e dissestes uma sentença pouco notada em nossos tempos: como a saúde e a vida do enfermo dependem do bom ou do mau médico, de igual modo a honra do príncipe depende do bom ou do mau cronista. Em que medida isso estima o ofício de cronista? Na medida que julgo que de uma só pena dependem a fama e a infâmia do príncipe e de toda a sua República, pois por meio de seu testemunho os homens são famosos ou infames enquanto dura o mundo. Os cronistas são quem fazem presente todo o passado e o que nos fazem perpétuos em todos os séculos futuros. Porque as crônicas sempre vivem e jamais morrem, passando de nação em nação publicando nossos méritos ou deméritos como podes ler no Velho Testamento que trata de coisas desde a criação do mundo até a vinda de Cristo nosso redentor, e no Novo, desde Cristo até o fim do mundo. As crônicas excedem em perpetuidade a todas as pirâmides, colunas, troféus, mármores e todos os outros gêneros de edifícios antigos. São elas que nos dão ser e renome bom ou mau durante todo o mundo. Por essa razão, o cronista deve ser escolhido com grande diligência e prudência, cuidando para que não seja vil, ignorante, interessado, apaixonado, obrigado, vicioso, adulador, audaz, exagerado e mentiroso, mas, sim, verdadeiro, experto, cristão, virtuoso, ilustre ou nobre. Cipriano: Logo, o príncipe bom e cristão que queira deixar memória de si deve não apenas trabalhar bem, mas eleger um cronista que seja capaz de escrever sábia e corretamente? Basílio: Parece-me ser assim. Cipriano: E o que dirás de um que é sábio e virtuoso e que tem as outras partes que tu exiges para ser perfeito cronista, mas que não seja de raça nobre? Basílio: Na minha opinião, se sendo igual

\footnotetext{
${ }^{30}$ Passagem do Livro Secreto de Juan ou Evangelho Apócrifo de Juan.

31 "No princípio era o Verbo, e o Verbo estava com Deus, e o Verbo era Deus", passagem do primeiro capítulo do Evangelho de João.

${ }^{32} \mathrm{O}$ livro de Apocalipse de São João traz os quatro símbolos do Evangelho: São João evangelista é representado pela águia, Lucas pelo bezerro, Marcos pelo leão e Mateus pelo homem.
} 
nessas qualidades a outro, deve-se preferir o nobre para este ofício pelas razóes que tenho dito, embora não nego que a verdadeira nobreza que procede da virtude e da tão boa e vasta experiência daria a um plebeu o merecimento face a outros nobres (coisa que vemos acontecer algumas vezes), já que nesse caso ele seria mais do que um nobre. Se ele tem as outras partes que referi poderia ser admitido. Cipriano: O que chamas de cronista verdadeiro? Basílio: É tão essencial o cronista ser verdadeiro nesse caso que, ao não sê-lo, afronta a si mesmo, engana e (às vezes) infama o príncipe, mingua a República e toda a sua nação. Cipriano: Como é possível saber se uma crônica conta a verdade se é publicada até depois que o príncipe está morto e, ainda, (alguma vez) depois que filhos e netos, não restando testemunhos que a contradigam? Basílio: Algumas naçôes pecaram em este erro por sua própria paixão, outras, considerando os inconvenientes que isso poderia causar-lhes, continuando a escrever pouco, quase escreviam verdade aventurando a vida e, se mentiam, perdiam a honra. Mas agora a natureza humana é mais livre e curiosa, de sorte que muitos escrevem por si sem mandados, por ambição pela honra ou pelo aumento de ganhos, outros escrevem para adular o príncipe esperando mais prêmio de terras do que o bom renome da República. Há aqueles que escrevem por mando e prêmio do príncipe e que (como está dito) não sei se serão de todo corretos, como há também quem escreve pela obrigação da pátria, por opinião, paixão, amizade ou sobrenome. E, por fim, existem alguns (às vezes) que escrevem para vingar-se de quem não ousam ou não podem vingar-se com a espada. Todos esses inspiram pouca fé, pois seu fim é o interesse ou a paixão. O bom e verdadeiro cronista (segundo meu pobre juízo) há de ser como tenho dito: neutro, autêntico, táo livre e senhor de si que pura e sinceramente escreva somente a verdade, sem temor, amor, interesse, paixão ou obrigação. Cipriano: Logo, isto não poderá fazer o parente, o criado, o premiado, o natural nem o apaixonado amigo ou inimigo. Basílio: Náo sem suspeita. Cipriano: Mas, quem o fará? O que for livre dessas coisas e tiver as partes que já tenho referidas. Cipriano: Já compreendo, tu queres tornar a persuadir-me que escreverá melhor a verdade o que for livre (que é o bem nascido), porque sua nobreza obriga-o a todo ato nobre e porque as pessoas vis não saberão referir táo corretamente os atos notáveis e grandes? Basílio: Não duvides, amigo Cipriano, pois se colocarmos um rústico e um nobre em igual grau de ciência, o nobre escreverá melhor os atos do príncipe (pois nasceu e foi criado entre príncipes) e de forma mais verdadeira e autorizada do que um rústico que nunca presenciou porque foi criado em coisas baixas. Como isso já foi tratado e limitado outras vezes, passemos adiante. Cipriano: Estou satisfeito.

Fim do Segundo Diálogo

\section{DIÁLOGO III}

Cipriano Basilio


Cipriano: Crês (irmão Basílio) que o ilustre ou nobre aceita abaixar para exercer esse ofício? Basílio: Se o ofício é virtuoso, acreditas que o ilustre o recuse, sendo filho da virtude? Não creias. Pois, se notas, mais humildade se encontra no nobre do que no vil e mais no alto do que no baixo. Cipriano: Sendo isso assim como escrevem, tampouco é isso que tu tanto elogias. Basílio: Bem, parece que tens lido pouco. Júlio César ${ }^{33}$, sendo quem foi, não escreveu? Cipriano: Escreveu este sua própria história. Basílio: Salústio ${ }^{34}$ não foi nobre cidadão romano? E São João Evangelista ${ }^{35}$ (como dissemos), não era nobre? Cipriano: É verdade que esses e muitos outros notáveis escreveram antigamente, mas eu questiono os do nosso tempo. Basílio: Em nossos tempos, pessoas ilustres escreveram sobre aqueles três únicos príncipes que não sei quando se verão em uma idade seus semelhantes. Cipriano: De quais? Basílio: Do prudentíssimo Carlos V e do Cristianíssimo Frances de Valoys; ${ }^{36}$ não duvides que muitos escrevem sobre os presentes mas não querem assinar por diversos motivos, o que torna mais autêntica a sua escrita. Cipriano: Se (como dissestes) é difícil saber, então qual ilustre cronista pode escrever sobre o nosso monarca para que não lhe caluniem por agir por prêmio e qual ordem se dará para que os demais escrevam verdade? Basílio: O que tem ordenada aquele grande imperador dos Tártaros em sua República. Cipriano: Conte-me, se não for tedioso. Basílio: Na província de Citalcay ou Catayo (como chama no Oriente), localizada na grande Tartária, está este grande imperador chamado Cingisean, ${ }^{37}$ cujo poder se firma sobre numerosos reis, príncipes, varôes e Repúblicas. No dia em que realizam a escolha desse imperador elegem também, em segredo, doze homens como cronistas, os melhores que têm, e lhes dão o necessário sem que o imperador saiba. Cada um desses cronistas escreve por si uma história. Quando o imperador morre, esses homens embalsam seu corpo e o depositam na sala do grande conselho onde estáo [reunidos] todos os príncipes e senhores do império e lá leem em voz alta as crônicas dos doze cronistas mencionados. Nelas, todos eles resumem a verdade com mais de um parecer em um livro onde fidelissimamente se encontra escrito tudo o que o imperador fez de bom ou mau. Depois dessa cerimônia, enterram o corpo e em uma aldrava da sepultura atam com uma corrente o livro de sua história para aqueles que quiserem ver seus atos de vida e de governo, além de enviarem cópias do dito livro a todas as Repúblicas e potentados para atingir esse mesmo fim. Com esse gesto, sabem a pura verdade sem encobrimento algum. Cipriano: Isso seria coisa longa para mim, pois, se tu quiseres, poderá escusar tanto trabalho. Basílio: Sob título de amizade, tratas a mim como a ti te agrade. Tu sabes, amigo, que para negócio tão importante como esse que me pedes, outro conhecimento e suficiência se requer, pois, se eu te concedo o que tu me pres-

\footnotetext{
${ }^{33}$ Júlio César, imperador que governou Roma de 49 a.C a 44 a.C.

${ }^{34}$ Salústio, historiador romano e autor dos manuscritos que trazem as campanhas militares de Júlio César.

${ }^{35}$ João Evangelista ou Apóstolo João foi um dos doze apóstolos de Jesus. Compôs o Evangelho Segundo João, as três epístolas de João e o livro do Apocalipse.

${ }^{36}$ Frances de Valoys ou Francisco II, Francis II, rei da França entre 1559 e 1560.

${ }^{37}$ Cingisean ou Gengis Khan, imperador mongol em 1206.
} 
supóe (neutralidade, autoridade e verdade), faltariam as outras partes necessárias para o mérito tanto de um príncipe como de um monarca e desse por quem falas. Basta que me entendas no presente e consideres as partes que se requer para cronista para que saibas eleger pessoa capaz e digna de tal cargo. Portanto, prossiga em tuas perguntas sem perder tempo com isso. Cipriano: Estou satisfeito. Declare-me a que fim dissestes que tem a presença do cronista. Basílio: A causa por que se encontram poucas verdades em algumas crônicas é porque são escritas por relação alheia e não por vista própria. De sorte que a presença do cronista nos atos que escreve tem a mesma autoridade em relação ao que escreve por relação alheia, como o testemunho que depóe de vista em relação ao que depóe de ouvido. Mas como o testemunho que fala de ouvido tem pouca ou nenhuma fé, o historiador que escreve pelo que os outros lhe informam é indigno de ser acreditado. Para que saibas a explicação disso, veja o que encontrarás em um sermão e perceberás que cada um te contará de uma maneira diferente. Consultes mil que estavam em uma batalha e não encontrarás quatro que estejam conforme o que dizem que se passou, pois um quer elogiar a si mesmo, o outro a seu amigo e ainda outro quer prejudicar seu inimigo tirando-lhe a glória. Pensas tu, agora, se é possível acertar dizer a verdade aquele que se baseia na relação destes tais para escrever. Cipriano: Eu estou muito bem com tua opinião e considero essa parte tão essencial que me parece que sem ela a escrita será de pouca fé. Basílio: Acerca da importância da presença do cronista já nos mostraram aqueles quatro santos cronistas de Jesus Cristo que mais particularmente nos deixaram escritas tanto as palavras que disse como os milagres que operou. Se não, diga-me se importam menos as palavras que Cristo disse a São Felipe: quem vê a mim, vê meu Pai e, como fizeram os Apóstolos, curar um leproso ou ressuscitar um morto? ${ }^{38}$ Entendendo isso, o príncipe dos apóstolos disse a Cristo: Aonde iremos Senhor sem ti? pois tuas palavras são de vida. Quero dizer (irmão Cipriano) que tenho essa parte por táo importante que me parece que sempre deveria andar o cronista com seu príncipe. Porque a partir do seu falar e tratar poderia inferir a verdadeira inteligência de seus atos e vida, porque as palavras são o conceito do coração. Se o cronista não tem notícia certa e verdadeira delas, mal poderá narrar que tal é o príncipe de quem escreve. Cipriano: Verdadeiramente, eu vi louvar e alcançar as graves sentenças e palavras que disseram alguns príncipes por táo principais como seus atos e que às vezes fazem mais frutos as palavras e sentenças notáveis do que os feitos destacados. Basílio: Não duvides que o sábio cronista que quer fazer honra e mostrar claramente que tal é o seu príncipe deve notar e referir tão particularmente as suas palavras e os seus pensamentos notáveis como as suas obras. Especialmente quando o príncipe é pessoa douta, experta, prudente, de claro e grande entendimento, eloquente, virtuoso e cristáo, como o monarca de que tratamos. $\mathrm{O}$ cronista que verdadeiramente souber referir a doutrina

\footnotetext{
${ }^{38}$ Referência à passagem de João 14: "Se vós, de fato, tivésseis me conhecido, teríeis conhecido também a meu Pai; e desde agora vós o conheceis e o vistes". Solicitou-lhe Felipe: "Senhor, mostra-nos o Pai, e isso é suficiente para nós". Então Jesus ministrou-lhes: "Há tanto tempo estou convosco, e tu não me tens conhecido, Felipe? Aquele que vê a mim, vê o Pai; como podes dizer "mostra-nos o Pai?".
} 
e a sentença será digno de ser honrado e premiado por todos. Cipriano: Assim me parece. Diga-me, agora, que ciência se requer para ser cronista? Parece-me que o cronista há de ser prudente e sábio para saber e entender bem as coisas que se quer tratar e, depois disso, deve ter eloquência e bom estilo para saber declará-las. Porque é comum vermos alguns querendo exaltar o seu príncipe e, mesmo tendo matéria para isso, não sabem fazer, assim como outros que com muita facilidade sabem dizer e enaltecer o que quer. Quero dizer que, além da clara e sólida ciência que se pressupôe ter tal cronista, sua prudência e eloquência hão de ser tal que saiba narrar a vida e os atos do príncipe por tal ordem e termos que não hão de contentar com somente declarar corretamente o ânimo, as inclinaçóes, a natureza, fins e o bem e o mal do príncipe, mas, também, com sua eloquência, há de saber atrair os ânimos dos leitores (como bom orador), conduzi-los a venerar e imitar o bom e a lamentar e se afastar dos feitos maus que lerem, e que escreva com tanta sinceridade e autoridade que cause no leitor fé e atenção, pois dessas duas coisas depende a honra de quem se escreve e, ainda, a de quem escreve. Finalmente, há de procurar escrever pouco e verdadeiro sem deixar de incluir tudo o que for notável para que seu príncipe seja bem honrado e sua escrita fiável, celebrada e atual. Cipriano: Para o que mais serve ter ciência? Basílio: Para muitas e, especialmente, para entender e exprimir a prática e a inteligência do ânimo do príncipe (que pouco se diz), sem o qual nenhum escritor poderá referir ato nem coisa que náo seja confusa e duvidosa. Cipriano: $\mathrm{O}$ que chamas de prática e inteligência do ânimo e fins do príncipe? Basílio: Quais rústicos, que ignora as causas da produção, tens visto cultivar uma árvore durante dez anos para ter frutos? Esse tal se beneficiará do efeito que dá a árvore, mas não das causas que o resultaram. O mesmo digo se perguntas a um plebeu e a muitos cortesãos o que faz o Príncipe estando em guerra, e eles dirão que ele faz guerra mas não saberão dizer as causas intrínsecas que o moveram a fazê-la. Quero te dizer que não basta o cronista se contentar com saber e dizer os feitos empreendidos pelo seu príncipe, mas que também tenha perfeita inteligência para saber as causas porque os faz. Exemplo: se o príncipe realiza uma guerra, convém que seu cronista (a seu tempo) saiba as causas intrínsecas que o moveram a fazê-la para que assim possa explicar porque o príncipe resolveu empreender tal empresa. Cipriano: Segundo esse cronista, há de ser um conselheiro privado ou secretário dos conceitos do príncipe e (a seu tempo) deverá comunicá-los (por mais secretas que sejam) as causas essenciais de todos os atos, coisas e casos que podem ser escritos. Basílio: Esta é a minha opinião. Digo mais, pois o príncipe que não fizer isso contribuirá para que não se trate a total verdade sobre o que dele se escreve e que se dê pouca fé ao seu escritor. Porque (como antes dizia), a opiniáo comum é que Júlio César escreveu sua história, mas eu li em um autor sério que ele não a escreveu, mas, sim, um varão douto que escutava a cada dia todos os seus conselhos e atos e que fidelissimamente os escrevia como agora temos. Ouvi dizer também que em nossos tempos aquele grande imperador Carlos V, digno de imortal memória, fazia o mesmo com 
seu servidor dom Luís de Ávila ${ }^{39}$, autor dos comentários da jornada da Alemanha, assim como, poderia dizer, procedia de igual modo o papa Paulo III ${ }^{40}$; exemplos que mostram ser tão essencial essa condição que o escritor que carece desta notícia e comunicação intrínseca com o príncipe fica impossibilitado de escrever (como outras vezes disse), a não ser com erros e confusão.

Fim do Terceiro Diálogo

\section{DIÁLOGO IIII}

\section{Cipriano Basílio}

Cipriano: Tu pretendes, em efeito, segundo o que presumo com tuas palavras, que o perfeito cronista há de ser neutro para que escreva sem ódio, paixão nem obrigação. Há de ser livre de interesse e sujeição para que refira livremente o que sente. Há de ter vida limpa e sangue para que tenha autoridade sobre o que disser. Há de ser táo sincero, correto e verdadeiro que jamais refira (se é possível) a não ser a verdade ocular. Há de ser tão contínuo na casa do príncipe para que entenda e saiba muito particularmente suas palavras e obras ao declarar as que empregar segundo o propósito de sua história. Finalmente, há de ser tão hábil, capaz e eloquente que com sua ciência honre seu príncipe, se caso mereça, e com sua arte e eloquência edifique o leitor de seu escrito. Basílio: Segundo o melhor entendimento, essas são as partes que há de ter o bom cronista e o sábio escritor. Cipriano: Se também as entendes e ensinas, por que recusas este trabalho e queres defraudar a República de tanto fruto que se pode conseguir? Basílio: Já te disse que não me fales isto, porque embora entenda o que tu dissestes e eu tenha exercitado [esse ofício] em outro momento, não aceito fazê-lo agora. Cipriano: Por quê? Basílio: Porque já te disse. Cipriano: Não é causa bastante para se desculpar, pois a justa importunação é mais serviço do que o desgosto e, por isso, não deve ser recusada, principalmente do amigo que és tu; eu te peço como amigo e te persuado como cristão que aceites esta tarefa, pois disso não te resultará nada mais do que a honra. Por ser o sujeito que tratará sobre o supremo monarca da cristandade que (deixando de lado sua dignidade) é táo raro como pessoa, tão militante na religiáo e no governo da monarquia como nenhum outro existiu em estes muitos anos, tendo, além do mais (como consta), sangue e linhagem não tão modernos, não fazendo parte dos ilustres de Itália e nem possuindo tantos títulos em sua família como qualquer outro. Basílio: Com tua importunação me levarás a dizer coisas que eu preferia não dizer. Porque, na verdade, as coisas que dizes não se

\footnotetext{
${ }^{39}$ Don Luis de Ávila y Zúñiga, nobre e historiador espanhol na época de Carlos V.

${ }^{40}$ Papa Paulo III foi pontífice de 1534 a 1549.
} 
pode aproveitar e podem irritar alguém, de modo que mais sensato seria não dizê-las. Tu sabes (amigo Cipriano) que nessa nossa era um homem rico, embora seja vil em sangue e infame na vida, inábil e vicioso como pessoa, e que finalmente tenha todos os defeitos na vida, por dispor de riquezas pode estar em todas as partes como sendo respeitado, ouvido e acreditado, louvado, servido e acompanhado e ainda desejado por muitos homens grandes. O que náo ocorre o mesmo com um homem ilustre de sangue e em vida, douto e prudente, eloquente, generoso, desprendido, modesto, devoto, justo e, em conclusão, que tenha todas as virtudes que se pode desejar, mas por sua condição pobre, não há homem que o queira ver nem crer, sendo que todos fogem dele como da peste ora por medo que lhes peça algo ou por pensar que são obrigados a dar-lhe algo, ora por receio de que deva tratá-lo com algum respeito. O que quero dizer-te em bom castelhano é que mesmo que eu aceite o cargo que me pedes, traria dano ao príncipe e assistiria a minha opiniáo, fama e verdade da escrita perderem o crédito por eu ser pobre. Sendo assim, admita (eu te suplico) esta recusa que é tão legítima. Cipriano: Eu confesso que em nossa idade se estimam mais as riquezas do que as virtudes e que o rico vicioso e vil encontra em muitos lugares mais passagem do que o ilustre virtuoso pobre. Mas isso ocorre entre ricos vis ou nobres mesquinhos e viciosos, e entre a gente vulgar e plebeia que não compreende como o mérito da virtude e da nobreza excedem a riqueza e os bens momentâneos. Por essa razão, não admito tua recusa e apresento-te minha demanda de novo por tudo o que deves a quem tu és e à República onde vives e ao bom nome que pretendes manter. Basílio: Tu me pressionas tanto que não vejo como não me decidir. Mas o que falta em outros para poder levar adiante este negócio? Cipriano: É bem verdade que alguns que escrevem sabem o que outros ignoram, de modo que de nossa parte e também o contrário cada um escreve segundo sua intenção e fim para o bem e para o mal. É justamente por isso que eu tanto te importuno, porque sei que dentre todos estes (como sabes), os adversários escreverão o que for mau e silenciarão o que for bom e os naturais (ao contrário disso) publicarão o que for bom e se calarão sobre o que entenderem como mau. De modo que em ambas as partes haverá faltas e excessos, além de pouca fé tanto aos que excederem por interesse como aos que faltarem [em dizer] por preferência. Mas tu, que não te conduz nem por um nem por outro e que dispóe de todas as outras qualidades necessárias (já aqui posto), poderás contentar-me aceitando [este ofício] e impondo ao povo cristão este trabalho oferecido a ti (que, a meu ver, não será pequeno), pois, como sabes, não nascemos apenas para nós, mas também para quem nasceu conosco. Basílio: Pela obrigação que tenho ao bem comum que dizes e pela tua amizade particular quero condescender com teu pedido sob duas condiçôes: a primeira que eu seja livre para escrever e, a segunda, que eu esteja presente e seja informado (em seus tempos) pelo príncipe sobre as causas intrínsecas de seus negócios e atos, pois, sem isto, eu faltaria com meu dever e não seria comodamente servido. Cipriano: Eu me ofereço a conseguir do príncipe o que me pedes, pois ele sabe que o bom e verdadeiro cronista não há de ser nomeado, nem obrigado, nem súdito, nem baixo, nem 
adulador, nem apaixonado, nem dissimulado, nem interessado, mas, sim, livre, ilustre, discreto, verdadeiro, neutro, capaz, virtuoso e bom cristão. Que escreva com sua pena o que todos aprovarem com sua língua. Dou-te, finalmente, graças quanto posso pelo favor que me concedes. Basílio: Não me imponhas a minha palavra se tu não possas cumprir com tua promessa. Cipriano: Duvidas disso? Basílio: Sim, duvido, porque os príncipes difíceis de contratar poucas vezes comunicam com alguém seus intrínsecos conceitos, e o cronista que não tem verdadeira informação das causas essenciais que o moveram a fazer a guerra, mal poderá escrever perfeitamente sobre ela. Dizeis a verdade [quando comentastes] que o médico que cura o enfermo somente por acidente e ignora as causas essenciais da enfermidade não escapa de cometer mil erros. Mas tu podes inferir pelos atos que observar o príncipe fazer. Basílio: Não é [prática] do sábio escritor adivinhar, mas afirmar o que sabe e escrever o que ele mesmo ouve e vê, tal como fez São João evangelista em todo o discurso de sua sagrada crônica. Cipriano: Mas é impossível a todo cronista conhecer o passado do príncipe para narrar a sua genealogia e compreender por inteiro a pessoa, escrever a disposição de seu corpo, a promoção de seus membros, sua constituição e costumes, a virtude de suas capacidades interiores e exteriores, sua fisionomia, sua vida e o seu governo. Basílio: Mas mais impossível será escrever a verdade se se ignora tudo o que dissestes. Pois as partes mais essenciais de todo bom cronista são a narrativa da genealogia de onde descende [o príncipe], a proporção e disposiçấo que ele tem, a fisionomia de seu gesto, a sua idade, estrutura e condiçôes, e a excelência ou baixeza de suas capacidades interiores e exteriores, partes estas [que ajudam a] inferir sobre os seus atos de vida e de governo. Cipriano: É verdade que o príncipe sábio vence as suas más inclinaçôes (se tem algumas) e que muitos mentem os sinais (como dizem), mas eu tenho por muito necessário e importante que o cronista saiba todas essas particularidades para que sua história seja mais verdadeira. Porque se essa lei fosse assegurada por todos, duvidaríamos nas histórias passadas e poucos ousariam escrever sobre os presentes. Basílio: Creia-me, amigo Cipriano, que a honra e a autoridade do príncipe não consistem em grande volume de adulaçóes incertas, mas na boa e séria escrita de autor sábio e verdadeiro que em poucas folhas inclua quantas coisas notáveis o príncipe disse e fez em sua vida. Que saibas, igualmente, escrever por esses termos para que todos possam aprovar e alegar como coisa autêntica e verdadeira. Cipriano: Mas, para uma crônica ser muito autêntica, não bastaria que o príncipe comentasse sobre quem escreve, como fizeram Júlio César e Carlos Quinto? Basílio: Sim, bastaria, se o príncipe comentasse a verdade e corrigisse fielmente todas as superficialidades e lisonjas que se usam no mundo. Mas, ao não proceder assim, como vês, seria dobrada a infâmia a tal príncipe no momento em que todos entendessem, ao passarem os olhos e colocarem as mãos na sua crônica, que ele consentiu que nela se tratassem coisas alheias à verdade. Este tal ganharia o prêmio de mentiroso e quando dissesse a verdade ninguém acreditaria nele. Cipriano: O desejo de ambição e glória leva muitas vezes o príncipe a dissimular algumas adulaçôes em sua crônica, ainda que não sejam 
verdadeiras. Basílio: A liberdade e o bom entendimento de cada sábio condenam-no como sendo um cego, ainda que ele não pense. Cipriano: Logo, o príncipe que queira deixar de si bom nome e fama não há de consentir que se escreva em sua crônica coisa que os presentes e os futuros não julguem por verdadeira? Basílio: Quem duvida disso?

Fim do Quarto Diálogo

\section{DIÁlOGO V}

\section{Cipriano Basilio}

Cipriano: $\mathrm{O}$ que me dirás, amigo Basílio, do cronista que finge o que não foi, encobre o que náo merece e rebaixa quem deveria ser prestigiado, exagera com palavras vãs ao escrever matérias que poderiam caber em uma folha? Basílio: Esse tal seria melhor chamado de poeta de ficçóes do que historiador de verdades. Cipriano: E aquele que escreve por desejo, pedido ou para adular o príncipe em troca do que lhe dão ou do que lhe prometem? Basílio: Chama esse (a meu ver) infamador de seu príncipe e enganador de si mesmo, pois encobre a verdade que sabe para publicar a vã arte que ele inventa. Cipriano: Logo, o perfeito cronista deve ser escritor verdadeiro com toda virtude e testemunho de toda verdade, breve e sucinto, autêntico, alheio à paixão e ao interesse, e testemunho pessoal sobre o que afirmar. Basílio: Estas e outras partes se requerem em todo bom cronista e não como em algumas Repúblicas onde se contentam com incapazes. Cipriano: Quem chamas de incapazes? Basílio: Aos que são idiotas em ciências, grosseiros em estilo, baixos de conhecimento, faltos de memória, obrigados, tardos para entender, vis em sangue, obscuros em vida e alheios a toda virtude e graça. Quem entretém esses tais? Basílio: O príncipe descuidado e mau aconselhado, porque o sábio nem permite mau cronista para a sua história nem o médico inexperiente para sua enfermidade. Cipriano: $\mathrm{O}$ que ocorre para haver tấo notável descuido em assunto de tanto importância? Basílio: [A culpa] é dos privados e favoritos dos príncipes ora porque lhes importunam, ora pelo que lhes dáo, deixando muitas vezes de ter em conta o que seria honra e saúde para seu príncipe, e informando-o que um é muito capaz para tal ofício ainda que tenha todos os defeitos que tenho dito. Cipriano: De fato, o ministro que direciona a seu príncipe um cego como guia e um incapaz como cronista é digno de grande pena, pois não só danifica a honra do príncipe, como também priva da fama todos os nobres e valorosos do reino, fazendo com que os maus e facínoras sejam exaltados e as suas maldades encobertas. Basílio: Melhor faziam (a meu ver) os Cântabros no tempo em que conservavam suas boas e antigas leis, pois não admitiam homem de ofício público sem passar por um exame público e um reexame secreto. Cipriano: Quais são os homens de ofícios públicos? Basílio: Os que 
exercitam ofícios que estão ordenados para o bem comum de todos, como os príncipes, juízes e outros ministros da justiça, os médicos, cronistas e outros dessa maneira. Deixando de lado as cerimônias que se usam com outros ofícios, porque não interessam muito para o propósito que tratamos, quero contar-te o que faziam com o cronista: no dia em que aprovavam-no para este ofício, coroavam-no com uma coroa de louro que continha dezesseis flores como sinal de que ele era possuidor de todas as partes que devem ter o bom cronista. Cipriano: Por certo que o costume era bom, mas, diga-me, quais eram estas dezesseis partes do cronista? Basílio: Se bem notastes, vais perceber que eu já mencionei ao longo de nosso diálogo.

Cipriano: Isso foi mencionado em diversas partes. Mas digas agora, em conjunto, se não te importas. Basílio: Concordo.

1. Que seja filho de nobres, pois, por não faltar-lhe o sangue de onde descende, não escreverá coisa que não seja certa e verdadeira.

2. Que seja claro e limpo na vida e nos costumes para que se dê fé à sua escrita, já que a ordenação e a escrita do mau não deve receber o crédito do bom.

3. Deve ser criado e experiente nos atos Régios e grandes do Rei e do Reino, porque aquele que carece desta prática náo consegue remediar depois nem com arte nem com retórica.

4. Deve ter grande conhecimento, claro e constante, excelente e boa memória, pois o que tem baixo conhecimento e a falta de memória mal poderá ordenar uma crônica sobre um grande momento.

5. Deve ter excelente, justa e valiosa disposição para que nem o temor nem o amor forcem a sua vontade ao medir cada ato, mas somente a razão, se for digno de infâmia ou de glória.

6. Há de ser verdadeiro em tudo, para que não perca o crédito de toda sua escrita por uma proposição falsa.

7. Há de ser sério e constante para que nem o louvor o enalteça nem o interesse o abata, porque o varão leviano e ambicioso é facilmente persuadido a escrever, em desonra de um e em adulação de outro, coisas tão alheias à verdade que póem em risco a fé das outras crônicas verdadeiras.

8. Há de falar pouco e notar muito se quer escrever como um sábio, porque notar as coisas notáveis faz dele um autor excelente e, o falar pouco, dá a ele fama de sábio e discreto.

9. Ao escrever, há de ser muito vigilante e prudente, breve e instrutivo, sincero e claro, para que todos o entendam, assim como douto e elegante, para que todos o creiam e o imitem.

10. Há de ser neutro na inclinação e na natureza para que nem a paixão lhe cegue nem a obrigação da natureza lhe force a não proceder igualmente em tudo o que escreve.

11. Há de ser alheio à servidão, se quer que sua escrita seja livre de suspeita, porque ao servidor inclinado não é justo que seja acreditado em coisas do momento. 
12. Não deve ser obrigado nem interessado porque de homem entusiasmado com algum interesse ou outra obrigação não se espera uma sentença correta.

13. Há de ser alheio a toda bajulação se quer ser tido por conhecedor e verdadeiro, porque o homem bajulador não alcança a verdade e a autoridade.

14. Há de estar presente em todos os eventos que narrar com sua pena, pois é certo que não se dará inteira fé em quem depóe de ouvido.

15. Há de saber todos os segredos do príncipe e há de se instruir acerca de todas as causas, pois, sem conhecê-las, mal poderá julgar somente pelos seus efeitos.

16. Por fim, há de ser livre tanto para não esperar algo do Rei nem da glória pública do mundo, porque qualquer um destes dois fins o condenam por interessado.

Cipriano: São tantas as condiçóes exigidas para um cronista que poucos estarão meritoriamente capacitados para ser. Basílio: Acreditas que se houver muitos a história vai ser melhor? Verás que muitas vezes se contradizem e se confundem na medida que uns tiram a fé dos outros e, no fim, nenhum é acreditado. Quisera Deus que se houvesse somente um (com as qualidades que disse) para escrever sobre cada príncipe, não teria tanta variedade de histórias no mundo. Cipriano: Queira Deus que daqui em diante se faça melhor. Mas, voltando a falar sobre os povos de Cantábria, o que significava a coroa de louros que colocavam na cabeça do cronista escolhido? Basílio: As virtudes e os méritos de sua excelente pessoa, a religião e a santidade de sua vida limpa, a integridade e verdade com que escrevia sua crônica, como acima disse, e, como um virtuoso, recebia uma estátua posta em público ao lado dos varôes ilustres como gesto de seu valor. Cipriano: Com tão honrados prêmios, grande obrigação cabia a ele que com muita fidelidade e cuidado deveria exercitar o seu ofício. Mas, diga-me, por que em nossos tempos não os premiam dessa maneira? Basílio: Porque os cronistas passados eram indicados somente por homens famosos e virtuosos e os cronistas do presente por importunaçóes de ministros favoritos e privados. Cipriano: Logo, essa matéria não é decidida por mérito próprio, mas por desejo alheio? Basílio: Correto. Por isso, verás que as crônicas dos príncipes são tidas quase por fabulosas bajulaçôes. Cipriano: Grande mal é haver tão pouco interesse em coisa tão importante. Eu quero advertir nosso príncipe acerca disso, pois (em todas as coisas tem estado próximo da razão) estou certo de que mandará dar boa ordem também em relação a isso. Penso que sobre esta matéria não há nada mais que possamos tratar; fique com Deus que eu quero regressar à casa, porque há tempos que não tenho estado nela. Basílio: Deus te guie, irmão Cipriano, que eu também farei o mesmo, pois creio que me aguardam para o jantar. 


\section{Documentação primária}

FERNÁNDEZ DE OVIEDO, Gonzalo. Libro de la Cámara Real del principe Don Juan, ofícios de su casa y servicio ordinário. Edición de Santiago Fabregat Barrios. Valencia: Universitat de València, 2006.

NAVARRA, Pedro de. Diálogos de la preparacion de la muerte, dictados por el Illustrissimo Reverendissimo Señor Don Pedro de Navarra, Obispo 9e de Comenge y del Consejo Supremo del Christianissimo Rey de Francia. Toulouse: Casa de Jacobo Colomerio impresor de la universidad, 1565.

NAVARRA, Pedro de. Dialogo qual debe ser el chronista del principe. Materia de pocos aún tocada. Dirigidos al catolico Rey de España Don Phelipe de Austria segundo deste nombre. Toulouse: Casa de Jacobo Colomerio, impresor de la universidad, 1567.

PÉREZ DE GUSMÁN, Fernán. Generaciones, semblanzas e obras de los excelentes reys de España D. Enrique III y D. Juan el II. Y de los venerables Perlados, y notables Caballeros que en los tiempos de estos Reys fueron. Ordenadas por el noble caballero Fernan Perez de Guzman. Corregidas y emendadas y adicionadas por el doctor Lorenzo Galindez de Carbajal del Consejo de sus Altezas. Madrid: Imprenta de D. Gerónimo Ortega e Hijos de Ibarra, 1790.

SAN JOSÉ, Jerónimo. Genio de la Historia. Madrid: Imprenta de Don Muñoz del Valle, 1768, segunda impressão.

\section{Referências}

BAUTISTA PÉREZ, Francisco. Historiografía y poder al final de la Edad Media: en torno al oficio de cronista. Ediciones Universidad de Salamanca, Stud. hist., Ha. mediev., 33, 2015. CABELLO PORRAS, Gregorio. Pedro de Navarra: revisión de un humanista. Bibliografía repertoriada de los siglos XVI-XVII. Revista Lectura y Signo, 3, 2008.

DICCIONARIO de Autoridades, tomo IV, 1734. Disponível em: http://web.frl.es/DA.html. Acesso em: 9 nov. 2019.

FERRERAS, Jacqueline. Les dialogues espagnols du XVIe siècle ou l'expression littéraire d'une nouvelle conscience. Paris: Didier Érudition, 2002.

GOÑI GAZTAMBIDE, José. Pedro Labrit de Navarra, obispo de Comminges. Su vida y sus obras (c. 1504-1567). Revista Principe de Viana, Espanha, Ano 51, n. 190, p. 559-596, 1990.

HERNÁNDEZ MARTÍNEZ, Pedro. La memoria de la historia oficial: Crónicas y cronistas en la España de los Reyes Católicos. Revista EPCCM, n. 15, 2013. 
LiÇÓES PARA SER O CRONISTA DO REI: UM ESTUdo DOS DIÁLOGOS SOBRE QUEM DEVE SER O CRONISTA DO PRÍNCIPE, de Pedro de Navarra

Maria Emília Granduque José

KAGAN, Richard. Los cronistas y la corona. La politica de la historia en España en las Edades Media y Moderna. Madrid: Marcial Pons, 2010.

LÉROY, Beatrice. L'historien et son roi. Essai sur les chroniques castillanes, $\mathrm{XIV}^{\mathrm{e}}$ et $\mathrm{XV} \mathrm{V}^{\mathrm{e}}$ siècles. Madrid: Casa Velázquez, 2013.

RALLO GRUS, Asunción. La escritura dialética: estúdios sobre el diálogo renacentista. Málaga: Universidade de Málaga, 1996. 